\title{
Comparative trial with highly purified natural ACTH, synthetic ACTH 1-24 peptide and synthetic ACTH 1-39 peptide
}

\author{
By P. J. Brombacher, H. J. Buytendijk and F. Maesen
}

From the Departments of Clinical Chemistry and Diseases of the Chest, Joseph Hospital, Heerlen, The Netherlands

(Eingegangen am 27. Januar 1969)

The intensity and duration of the adrenocortical stimulation; produced by highly purified natural porcine ACTH (44 U/ml), synthetic ACTH 1-24 peptide $(0.44 \mathrm{mg}$ tetracosapeptide $/ \mathrm{m} /)$ and synthetic ACTH 1-39 peptide $(0.4 \mathrm{mg} 1-39$ peptide/ml) with all preparations dissolved in a gelatin solution, were investigated in one trial with a total of 18 healthy volunteers.

The activity of synthetic ACTH 1-39 peptide significantly exceeds that of the synthetic 1-24 peptide, but is of shorter duration than that of the natural peptide.

An insgesamt 18 gesunden Probanden wurden Wirksamkeit und Dauer einer Stimulation der Nebennierentinde mit natürlichem ACTH und synthetischen ACTH-Peptiden untersucht. Geprüft wurden hochgereinigtes natürliches ACTH vom Schwein (44 IE/ml), synthetisches ACTH 1-24 Peptid $(0,44 \mathrm{mg}=44 \mathrm{IE} / \mathrm{ml})$ und synthetisches ACTH $1-39$ Peptid $(0,4 \mathrm{mg}=44 \mathrm{IE} / \mathrm{m} l)$, die jeweils in einer Gelatinelösung gelöst wurden.

Die Aktivität des synthetischen ACTH 1-39 Peptides ist signifikant höher als die des $1-24$ Peptids, aber von kürzerer Dauer als die des natürlichen Peptids.

During long term treatment of patients with corticosteroids many clinicians require a means of reactivating the adrenal cortex which is therapeutically more or less suppressed. This is notably the case in the treatment of bronchial asthma, theumatic disease and simular affections.

Up till some years ago some more or less highly purified corticotropin preparations of animal origin were frequently used for the stimulation of the adrenal cortex. As a matter of fact there was always the danger of sensitising the patient towards the animal protein with all the unwanted consequences such as anaphylactic shock in all its forms. These effects were seen indeed in about five percent of people repeatedly undergoing this therapy $(1,2)$. For those reasons an iatrogenically inactivated adrenal cortex was often preferred as presenting a less serious risk than that accompanying regular administration of non-human protein hormone.

This deadlock was solved by the availability of a polypeptide with corticotropic activity synthesized by SCHWYZER and KAPPELER (3). This peptide of fully synthetic origin did not induce sensibilization which was also demonstrated with skin tests on patients known to react allergically to animal corticotropin (4). The non appearance of reactions came up to expectations because the sequence of the 24 amino acids of the synthetic product is the same as that in part of the natural ACTH molecule for many animal species and man (5). A certain disappointment however was felt when it became evident that the duration of action of the synthetic peptide was much shorter than for the natural hormone. Nevertheless with adequate dosage the effect was the same for both preparations for some hours after intravenous or intramuscular administration as measured by the increase of plasma cortisol levels. As was expected a very satisfactory effect was seen on continuous intravenous infusion (6), but there are practical objections to this.

Consequently a definite want is felt for a synthetic preparation comparable to natural corticotropin with respect to duration of action and adrenal cortex stimulatory effect, but without the allergic properties of the latter.

Possibly the shorter duration of action of the synthetic 24 amino acid peptide could be explained by the absence of the last part of the natural molecule containing amino acids number 25 to 39 . It could be that this tail of the molecule offers a certain stereochemical protection against breakdown viz. inactivation by the human organism.

In order to obtain more detailed information we performed a comparative investigation with highly purified porcine corticotropin ${ }^{1}$ ), and two synthetic polypeptides containing viz. $24^{2}$ ) and $39^{3}$ ) amino acids. In order to secure about the same depot properties on intramuscular administration for the three preparations, gelatin was added to all peptide solutions, this being a procedure often used with the natural hormone.

\section{Material und Methods}

The investigation was performed with eighteen healthy cooperative volunteers, all males between 18 and 26 years old, who had never previously received either corticosteroids or corticotropin. They stayed in bed during the experiment.

Blood samples were taken at 9 a. m. (time -1 h.), 10 a. m. $(0$ h.), 14 p. m. ( +4 h.), 16 p. m. ( +6 h.), and 18 p. m. ( +8 h.).

In this trial the time of injection (10 a. m.) was the same in all volunteers, the dosage $(1 \mathrm{~m} /)$ was the same for all types of preparations.

1) Cortrophin, Organon.

2) 1-24 peptide, cortrosyn, Organon.

3) 1-39 peptide (synthetic), Organon. 
The quality of ACTH gelatin preparations is dependent on the properties of the gelatin used. Therefore one lot of gelatin was used for manufacturing the three different preparations. The ACTH 1-39 peptide showed a potency of $110 \mathrm{IU} / \mathrm{mg}$ in the subcutaneous ascorbic acid depletion test.

The above mentioned preparations were manufactured in the following concentrations:

\section{$44 \mathrm{U} / \mathrm{m} /$ highly purified natural porcine ACTH \\ $0.44 \mathrm{mg}=44 . \mathrm{U} / \mathrm{m} /$ synthetic $1-24$ peptide \\ $0.4 \mathrm{mg}=44 \mathrm{U} / \mathrm{m} l$ synthetic $1-39$ peptide.}

The investigation was performed in 6 randomised "blocks", each block consisting of 3 healthy volunteers in whom the preparation was tested simultaneously and at any time under equal circumstances:

The ACTH packings to be used for each block were only distinguished by random numbers, denoting the order to be observed in each phase of handling (injecting, sampling of blood) of the volunteers. The volunteers were assigned to the order numbers in some convenient way. As a consequence the distribution of both volunteers and order numbers was random with respect to the treatment.

The corticotropic effect was evaluated from the plasma cortisol levels. The plasma corticoid values were determined using the fluorometric method of MatringLy (7).

Initial values were determined one hour before and at the moment of the intramuscular injection. Blood samples for plasma cortisol determination were also taken after 4,6 and 8 hours.

\section{Results}

The plasma cortisol values found are given in the accompanying table 1 .

For each observation time after injection a separate analysis was made for the comparison of the three treatments. In order to meet at least approximately the basic requirements for the analyses (uniform scatter and Gaussian error distribution), all observed values were replaced by their logarithms.

Each analysis was carried out taking due account of the subdivision by blocks and of each patient's initial value, defined as the mean of his $-1 \mathrm{~h}$ and $0 \mathrm{~h}$ value. In this trial, however, the initial values were found to have exerted no demonstrable influence on the values at any time after injection, so that finally they were not accounted for in the comparison among the treatments.

Tab. 1

Plasma corticoid levels after administration of different peptides with corticotropic activity. Experiment in six randomised blocks

\begin{tabular}{|c|c|c|c|c|c|c|c|}
\hline Treatment & $\begin{array}{l}\text { Volun- } \\
\text { teer }\end{array}$ & Block & $\begin{array}{r}\mathrm{Pl} \\
-1\end{array}$ & 0 & coic & $\begin{array}{c}\mu \mathrm{g} / \\
6\end{array}$ & $8 \mathrm{ml}$ hrs. \\
\hline \multirow[t]{2}{*}{$\begin{array}{l}\text { Highly purified } \\
\text { natural porcine } \\
\text { ACTH dissolved in } \\
\text { gelatin } 44 \mathrm{U} / \mathrm{ml}\end{array}$} & $\begin{array}{r}1 \\
5 \\
9 \\
10 \\
14 \\
18\end{array}$ & $\begin{array}{l}\text { I } \\
\text { II } \\
\text { III } \\
\text { IV } \\
\text { V } \\
\text { VI }\end{array}$ & $\begin{array}{l}26.2 \\
24.2 \\
26.2 \\
27.2 \\
32.7 \\
26.4\end{array}$ & $\begin{array}{l}22.5 \\
23.2 \\
19.7 \\
20.2 \\
30.9 \\
20.0\end{array}$ & $\begin{array}{l}\mathbf{5 2 . 5} \\
53.0 \\
\mathbf{5 3 . 1} \\
\mathbf{5 7 . 5} \\
66.5 \\
60.0\end{array}$ & $\begin{array}{l}\mathbf{5 1 . 5} \\
60.6 \\
57.0 \\
64.0 \\
\mathbf{7 0 . 0} \\
\mathbf{5 3 . 7}\end{array}$ & $\begin{array}{l}43.2 \\
28.8 \\
44.7 \\
52.8 \\
49.0 \\
36.6\end{array}$ \\
\hline & & & 27 & 23 & 57 & 59 & 43 \\
\hline \multirow[t]{2}{*}{$\begin{array}{l}\text { 1-24 peptide } \\
\text { dissolved in } \\
\text { gelatin } \\
0,44 \mathrm{mg} / \mathrm{ml}\end{array}$} & $\begin{array}{r}2 \\
6 \\
7 \\
12 \\
13 \\
17\end{array}$ & $\begin{array}{l}\text { I } \\
\text { II } \\
\text { III } \\
\text { IV } \\
\text { V } \\
\text { VI }\end{array}$ & $\begin{array}{l}25.6 \\
23.4 \\
21.9 \\
19.7 \\
36.4 \\
25.3\end{array}$ & $\begin{array}{l}24.0 \\
21.8 \\
30.6 \\
13.4 \\
32.2 \\
21.2\end{array}$ & $\begin{array}{l}48.3 \\
37.2 \\
26.8 \\
52.8 \\
53.7 \\
52.1\end{array}$ & $\begin{array}{l}20.6 \\
16.2 \\
16.2 \\
31.0 \\
29.5 \\
31.2\end{array}$ & $\begin{array}{l}21.2 \\
17.5 \\
11.6 \\
18.1 \\
14.7 \\
18.0\end{array}$ \\
\hline & & & 25 & 24 & 45 & 24 & 17 \\
\hline \multirow[t]{2}{*}{$\begin{array}{l}1 \text {-39 peptide } \\
\text { dissolved in } \\
\text { gelatin } \\
0,4 \mathrm{mg} / \mathrm{ml}\end{array}$} & $\begin{array}{r}3 \\
4 \\
8 \\
11 \\
15 \\
16\end{array}$ & $\begin{array}{l}\text { I } \\
\text { II } \\
\text { III } \\
\text { IV } \\
\text { V } \\
\text { VI }\end{array}$ & $\begin{array}{l}21.2 \\
21.4 \\
33.0 \\
18.1 \\
28.7 \\
31.3\end{array}$ & $\begin{array}{l}17.4 \\
31.2 \\
15.0 \\
22.5 \\
26.9\end{array}$ & $\begin{array}{l}43.5 \\
52.1 \\
59.7 \\
55.3 \\
58.5 \\
53.7\end{array}$ & $\begin{array}{l}41.2 \\
43.7 \\
27.8 \\
51.0 \\
45.6 \\
32.8\end{array}$ & $\begin{array}{l}27.5 \\
27.2 \\
27.5 \\
28.8 \\
24.7 \\
20.6\end{array}$ \\
\hline & & & 26 & 23 & 54 & 40 & 26 \\
\hline
\end{tabular}

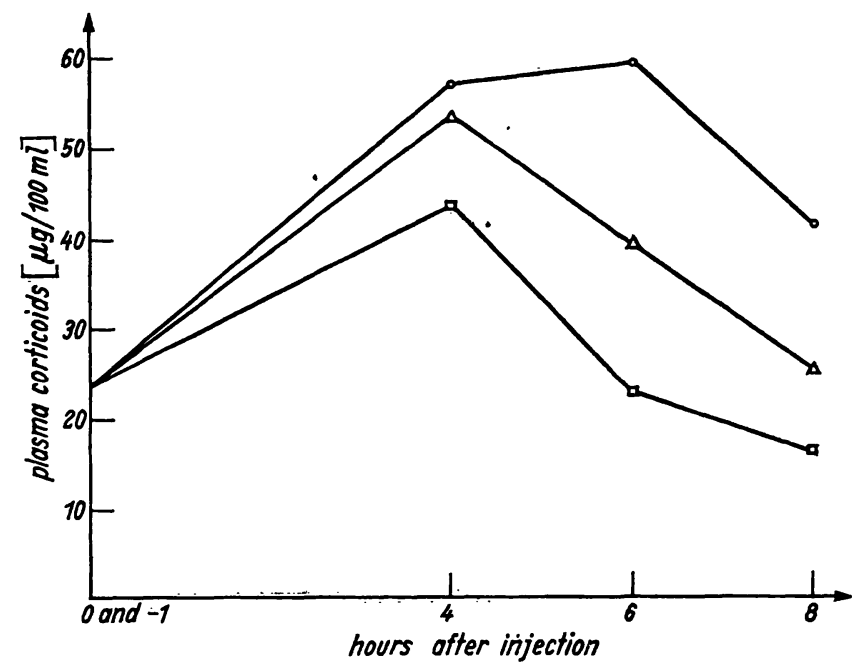

Fig. 1

Plasma corticoid levels after administration of different peptides with corticotropic activity. Experiment in six randomised blocks; retransformed means of six healthy volunteers after statistical analysis on the logarithms of the values. See text

$\multimap$ porcine ACTH $\Delta-\Delta 1-39$ peptide $\square-\square$ 1-24 peptide

For each observation time after injection the treatment means have been retransformed to their antilogarithms and plotted in the figure 1 . The same has been done with the general mean initial value.

\section{Discussion and conclusions}

From the statistical evaluation of the data obtained it appears that the activity of the $1-39$ peptide significantly exceeds that of the $1-24$ peptide both at $4 \mathrm{~h}$ and $6 \mathrm{~h}$. At $8 \mathrm{~h}$ there is still a suggestion of a difference in the same direction (two sided significance, level $\mathrm{P}_{2}=0.087$ ). The activity of the $1-39$ peptide does not differ significantly from the natural preparation at $4 \mathrm{~h}$, but it is significantly lower both at $6 \mathrm{~h}$ and $8 \mathrm{~h}$. The clinical results reveal that from the preparations tested the $1-24$ peptide in gelatin is least active. This is not surprising and is a confirmation of what we expected. The difference in response of highly purified natural ACTH and the synthetic $1-39$ peptide is more or less unexpected, since the main constituent of natural ACTH is the $1-39$ peptide. An explanation for this difference in activity could be the presence of smaller and higher molecular weight components in natural ACTH, which protect the $1-39$ peptide from inactivation by tissue enzymes at the site of injection.

\section{Literature}

1. Charpin, J., A. Zefiropoulo, J. Aubert, Ph. Ohresser and Ch. Boutrn, Presse méd. Paris 72, 3025 (1964). - 2. Arnoldsson H., Acta allergologica 8, 369 (1955). - 3. SchwYZRR, R. and $H$. Kappeler, Helv. chim. acta 46, 1550 (1963). - 4. BuYrendiJK, H. J. and F. MAesen, Acta endocr. K'hrn. 47, 613 (1964). 5. Hormann, K., Ann. Rev. Biochem. 31, 213 (1962). - 6. Walser, A., H. G. HAAS and F. Koll.RR, Helv. med. acta 30, 470 (1963). 7. Matringly, D., J. clin. Path. London 15, 374 (1962).

Dr. P. J. Brombacher de Wever-Ziekenhuis Heerlen, Netherlands 